\title{
Bioactive Compounds and Cytotoxicity of Ethyl Acetate Extract From Broussonetia luzonica (Moraceae) Blanco Leaves against Hepatocellular Carcinoma (Hepg2) Cell Lines
}

\author{
Franelyne P. Casuga ${ }^{1,2^{*}}$, Agnes L. Castillo ${ }^{1,2,3}$, Mary Jho-Anne T. Corpuz ${ }^{1,2,3}$ \\ 'Graduate School, University Of Santo Tomas, Espańa, Manila, PHILIPPINES. \\ 2Faculty Of Pharmacy, University Santo Tomas, Espańa, Manila, PHILIPPINES. \\ ${ }^{3}$ Research Center For Natural And Applied Sciences, University Of Santo Tomas, Espańa, Manila, PHILIPPINES
}

\begin{abstract}
Introduction: Broussonetia luzonica (Moraceae) Blanco is an edible and endemic plant in the Philippines. Other species of the plant are used traditionally in Chinese medicine to treat impotency and eye disorders and was proven to have anticancer potential. To date, there are no published scientific evidences yet to prove the cytotoxicity against hepatocellular carcinoma cell lines (HepG2) of $B$. luzonica. Furthermore, the bioactive compounds of the ethyl acetate leaf extract were determined. Methods: Bioactive compounds were determined using Gas Chromatography-Mass Spectrometry (GC-MS). To determine the $I C_{50}$, the percentage Hepg2 Cell inhibition of the extract at $200 \mu \mathrm{g} / \mathrm{mL}, 100 \mu \mathrm{g} / \mathrm{mL}, 50 \mu \mathrm{g} / \mathrm{Ml}, 25 \mu \mathrm{g} / \mathrm{mL}$ And $12.5 \mu \mathrm{g} /$ $\mathrm{mL}$ concentrations against (HepG2) was evaluated using 3-(4,5-Dimethylthiazol-2yl)-2,5-Diphenyltetrazolium Bromide (MTT) Assay. Results: GC-MS revealed the top three major bioactive compounds of ethyl acetate leaf extract based on quantity (\%). These are 1,2,3-propanetriol, monoacetate (21.21\%), phytol (20.28\%) and squalene (6.85\%). MTT assay showed that ethyl acetate extract at different concentrations exhibited marked inhibition of the HepG2. The concentration of the extracts that will inhibit $50 \%$ of the
\end{abstract}

cancer cell lines $\left(\mathrm{IC}_{50}\right)$ was also determined. The assay revealed that compared to positive control (doxorubicin) with $\mathrm{IC}_{50} 5.068 \mu \mathrm{g} / \mathrm{mL}$, Ethyl Acetate Extract statistically exhibited greater cytotoxic effect against HepG2 Cell Lines With $I C_{50} 1.118 \mu \mathrm{g} / \mathrm{mL}(P=0.001)$. Conclusion: The presence of several bioactive compounds in ethyl acetate extract from the leaves of $B$. luzonica confirms the importance of the plant in treatment of diseases. Furthermore, the extract manifested more potent cytotoxic activity than the positive control, indicating promising chemotherapeutic potential of the plant.

Key words: Endemic, Liver Cancer, GC-MS, MTT Assay.

Corresponding author: Franelyne P. Casuga, Dhe Graduate School, University Of Santo Tomas, Espana, Manila, PHILIPPINES.

Tel: +63 27112419 Cp: +639399042476

Email: fran_casuga@yahoo.com

DOI : 10.5530/pj.2016.5.15

\section{INRODUCTION}

Cancer is the leading cause of mortality and morbidity worldwide, representing a major public health burden in all parts of the world. world cancer report 2014 states that there were estimated 14.1 million new cancer cases, 18.2 million cancer mortality, and 32.6 million people living with cancer (within 5 years of diagnosis) in 2012 worldwide. ${ }^{1}$ Of these, more cases were in men (7.4 million) than in women (6.7 million). The number of reported cases is expected to rise to 24 million by $2035 .^{2}$ in addition, cancer causes one in every four deaths in the united states. ${ }^{3}$

A very malignant and most common type of cancer, hepatocellular carcinoma (HCC) is the third leading cause of cancer-related mortality worldwide. ${ }^{4}$ Since HCC is seldom detected early, high percentage of patients visiting health service facilities with symptoms of HCC are confirmed on malignant stage. ${ }^{5}$ Therefore, there is a need to address this alarming health threat to mankind.

Even though there are several approved chemotherapeutic agents available for preventing and treating cancer, the scientific community is still challenged to reduce the increasing incidence of this chronic disease. At present, there is a continuous and growing interest in search for safe and effective compounds that could prevent, reverse, and block cancer development in order to address the alarming health problem. ${ }^{6-8}$ These researches focus more on the use of available natural resources and further investigate different mechanisms leading to cancer which could be the possible targets in suppressing its emergence. ${ }^{9-11}$ Plants play a significant role in the prevention and treatment of diseases and can even prevent and minimize the adverse effects of conventional treatments. ${ }^{12}$ They can be source of chemical compounds of biological and pharmacological importance. History reveals that plants are sources of successful drugs, and will continuously be an important pool for screening lead compounds. ${ }^{13}$ among the successful chemotherapeutic agents derived from plants are vincristine and paclitaxel ${ }^{14}$ which lead researchers to evaluate cancer therapeutic potential of other plants. ${ }^{15-18}$

B. luzonica commonly known as himbabao or alukon is endemic in the philippines. Its leaves and flowers are locally eaten by filipinos as part of vegetable recipes. edible plants are not only source of nutrition but of medicinal value. ${ }^{19-21}$ Currently, there are no published studies on biological properties of the edible and endemic B. luzonica. ${ }^{22}$ However, several investigations on the other species of broussonetia which is $B$. papyrifera revealed various biologic activities. B. papyrifera exhibited marked cytotoxicity against breast, lung and liver cancer cell lines, ${ }^{23}$ showed antioxidant property ${ }^{24}$ and has the ability to inhibit certain tumor necrosis factor- $\alpha$ (TNF- $\alpha$ )and interleukin $1 \mathrm{~b}$ (IL1B) ${ }^{25}$ According to Sousa (2012), plantsunderthesamegeneracouldalsoexhibit thesamebiologicactivities. ${ }^{26}$ Therefore, chemical components of $B$. luzonica leaves and the bioactivity were investigated. this is the first time to report the bioactive compounds and the cytotoxicity of the ethyl acetate extract from the leaves of B. luzonica against hepg2 cell lines using 3-(4,5-dimethylthiazol-2-yl)-2,5-diphenyltetrazolium bromide (MTT) assay.

\section{MATERIALS AND METHODS}

Plant Sample

The plant specimen of $B$. luzonica, collected by the researcher from Solano, Nueva Vizcaya, Philippines on June, 2015. it was verified and authenticated at the UST Herbarium, Research Center for Natural and Applied 
Sciences, University of Santo Tomas and was assigned an accession number of 012978 .

\section{Extraction of Ethyl Acetate Extract}

The leaves of the plant were cleaned and air dried at room temperature for about 3 days. The dried leaves were ground using wiley mill model no. 2 (Arthur h. Thomas co.). About $3 \mathrm{~kg}$ of dried and powdered samples underwent $24 \mathrm{hrs}$ percolation using 3 liters of ethyl acetate as solvent for extraction. Extract was collected and percolation was repeated on the same plant sample..$^{27-28}$ The solvent present in the pool of the extract was evaporated to dryness using Heidolphrotavapor (Germany).

\section{The Gas Chromatography-Mass Spectrometry Analysis (GC-MS)}

Analysis of bioactive compounds from ethyl acetate extract obtained from the leaves of B. luzonica by GC-MS was done using Agilent Technologies GC systems (Gc-7890a/Ms-5975c Model, Santa Clara, CA, USA) equipped with Hp-5ms column (30 M Length X $250 \mu \mathrm{m}$ Diameter X 0.25 Mm Thickness of Film). Spectroscopic detection by GC-MS which is an electron ionization system had utilized high energy electrons of $70 \mathrm{ev}$. pure helium gas $(99.995 \%)$ was the carrier gas at a flow rate of $1 \mathrm{ml} / \mathrm{min}$. The initial temperature is set at $50^{\circ} \mathrm{C}$ to $150^{\circ} \mathrm{C}$ with ramp rate of $3^{\circ} \mathrm{C} / \mathrm{min}$ and holding time of about 10 mins. Finally, the temperature is increased to $300^{\circ} \mathrm{C}$ at $10^{\circ} \mathrm{C} / \mathrm{min}$. one microliter $(1 \mu \mathrm{l})$ of the prepared $1 \%$ sample of the extracts diluted with respective solvents was injected in a splitless mode. Relative quantity of the chemical compounds present in the extract of $B$. luzonica was expressed as percentage based on peak area produced in the chromatogram. GC-MS analysis was done in Nanocast Laboratory, Department of Physical Sciences, Mahidol University, Thailand.

\section{Identification of Chemical Constituents}

Bioactive compounds extracted from different extracts of B. luzonica were identified based on GC retention time on HP-5MS column and matching of the spectra with standards on computer software data (repliband mainlab data of GC-MS systems).

\section{MTT Assay}

MTT (3-4,5-Dimethylethylthiazol-2-Yl)-2,5- Diphenyltetrazolium Bromide) Assay is based on the method of Mossmann with some modifications. ${ }^{29}$ Hepg2 (Human Caucasian Hepatocyte Carcinoma) Cell Lines were seeded into 96-well plates with $5 \times 10^{5}$ cells $/ \mathrm{mL}$ and incubated at $37^{\circ} \mathrm{C}$ humidified incubator with $5 \% \mathrm{Co}_{2}$ for $24 \mathrm{hrs}$. Five concentrations of sample were used $(200,100,50,25,12.5 \mu \mathrm{g} / \mathrm{mL})$ in treating the cells and Doxorubicin $\mathrm{HCl}$ as positive control. Cells were treated with the above mentioned sample concentrations and control with $100 \mu$ l volume for each well and incubated for $24 \mathrm{hrs}$. At $37^{\circ} \mathrm{C}$ humidified incubator with $5 \% \mathrm{CO}_{2}$. After incubation, media from each well was removed and $20 \mu \mathrm{l}(\mathrm{MTT})$ with $5 \mathrm{mg} / \mathrm{mL}$ concentration dissolved in phosphate buffer saline pH 7.2 was added into each well containing the untreated and treated cells. The 96-well plate containing HepG2 cells was incubated for $4 \mathrm{hrs}$ at $37^{\circ} \mathrm{C}$ humidified incubator with $5 \% \mathrm{CO}_{2}$. After incubation, 200 $\mu \mathrm{l}$ of DMSO was added to each well and the absorbance was read at 570 $\mathrm{nm}$ using Corona Sh-1000lab Microplate Reader. The percentage growth inhibition was calculated using the following formula. ${ }^{30}$

$$
\% \text { Cell Inhibition }=100-\{(\text { As- Ab }) /(\text { Ac-Ab })\} X 100
$$

Where,

As $=$ Absorbance value of Sample Compound

$\mathrm{Ab}=$ Absorbance value of Blank

$\mathrm{Ac}=$ Absorbance value of Control
From the percentage inhibition, concentration that could inhibit or kill $50 \%$ of cancer cell population or $\mathrm{IC}_{50}$ was calculated statistically using graphpad prism software.

\section{Statsitical Analysis}

The results were expressed as mean $\pm \mathrm{sd}$ of three trials. $\mathrm{IC}_{50}$ estimates for Hepg2 cell lines were computed based on \% inhibition values using four parameter logistic model, performed at graphpad prism version 6.0 (graphpad soft ware, la jolla california usa, www.graphpad.com). To determine, if there is significant difference between the $\mathrm{IC}_{50}$ of the control and the extracts, results were treated with analysis of variance followed by tukey's post-hoc analysis ${ }^{31}$ to determine which pair of the extracts significantly differ from one another using spss version 20-32 bit.p values of $<0.05$ were considered statistically different.

\section{RESULTS}

Since the discovery of successful chemotherapeutic agents obtained from plants, vast number of studies on plants increases. ${ }^{32,33}$ Isolated compounds from plants having cancer healing potential were also investigated for possible new source of chemotherapeutic agents. ${ }^{34}$ This investigation was conducted to determine the chemical compounds present in all the extracts. Furthermore, to study the cytotoxicity of the different crude extracts from the leaves of $B$. luzonica against hepatocellular carcinoma (HepG2) cell lines as compared to a standard drug, doxorubicin. GC-MS confirmed that the ethyl acetate crude extract has several bioactive components. Based on abundance, the top three major compounds in the extract are phytol (20.288\%), 1,2,3-propanetriol, monoacetate $(21.211 \%)$ and squalene $(6.8 \%)$. Table 1 shows the identified bioactive compounds present in ethyl acetate extract. Their identification and characterization are based on their elution order or retention time on a HP-5MS column. The retention time ( $\mathrm{min}$ ), molecular formula and the amount in \% of these compounds are also presented. Figure 1 represents the GC-MS chromatogram of the ethyl acetate extract.

The extract and positive control exhibited marked Hepg2 cell inhibitory property at various concentrations as shown in Figure 2.

Figure 2a shows the inhibitory effect of Doxorubicin against Hepg2 Cells. At $20 \mu \mathrm{g} / \mathrm{Ml}$, it can inhibit $80.80 \%$ of the cancer cells while at 1.25 $\mu \mathrm{g} / \mathrm{Ml}$, It can inhibit $17.10 \%$ of the cancer cells. Figure $2 \mathrm{~b}$ shows that $B$. luzonica ethyl acetate leaf extract inhibited $82.62 \%$ and $65.16 \%$ of Hepg2 Cells at $200 \mu \mathrm{g} / \mathrm{Ml}$ and $12.5 \mu \mathrm{g} / \mathrm{Ml}$ concentrations, respectively. Figure 3 shows the $\mathrm{IC}_{50}$ of the extract compared to the standard (Doxorubicin). Ethyl Acetate extract showed the more potent cytotoxicity having $\mathrm{IC}_{50}$ of $1.12 \mu \mathrm{g} / \mathrm{Ml}$ than Doxorubicin having $\mathrm{IC}_{50}$ of $5.06 \mu \mathrm{g} / \mathrm{Ml}$.

\section{DISCUSSION}

Based on studies, some of the constituents revealed by GC-MS are biologically active compounds. They were proven to possess pharmacologic activities which may contribute to the cytotoxic activity of the plant under study. Phytol, precursor of synthetic vitamin e and vitamin $\mathrm{k}$ was found to be cytotoxic against breast cancer cell lines (mcf7). ${ }^{35,36}$ Propanetriol-monoacetate was confirmed to be present in other plants revealing antimicrobial, anti-inflammatory, diuretic and anticancer effects. ${ }^{37}$ Same compound was proven to be a precursor of tricetin (antifungal) but may also serve as a prodrug and vehicle for anticancer agents. ${ }^{38}$ Squalene has antioxidant, chemopreventive, antitumor and hypocholesterolemic activities. ${ }^{39-40}$ These compounds are present in ethyl acetate extract from $B$. luzonica leaves which supports the cancer therapeutic potential of the plant against hepg2 cell lines.

Based on the criteria of United States National Cancer Institute, a compound is classified as cytotoxic if it has an $\mathrm{ic}_{50}$ of $<20 \mu \mathrm{g} / \mathrm{ml} .{ }^{41}$ Statistical analysis revealed that there is significant difference between the $\mathrm{IC}_{50}$ of 


\section{Table 1: Bioactive Compounds of Ethyl Acetate Extract from B. Iuzonica leaves}

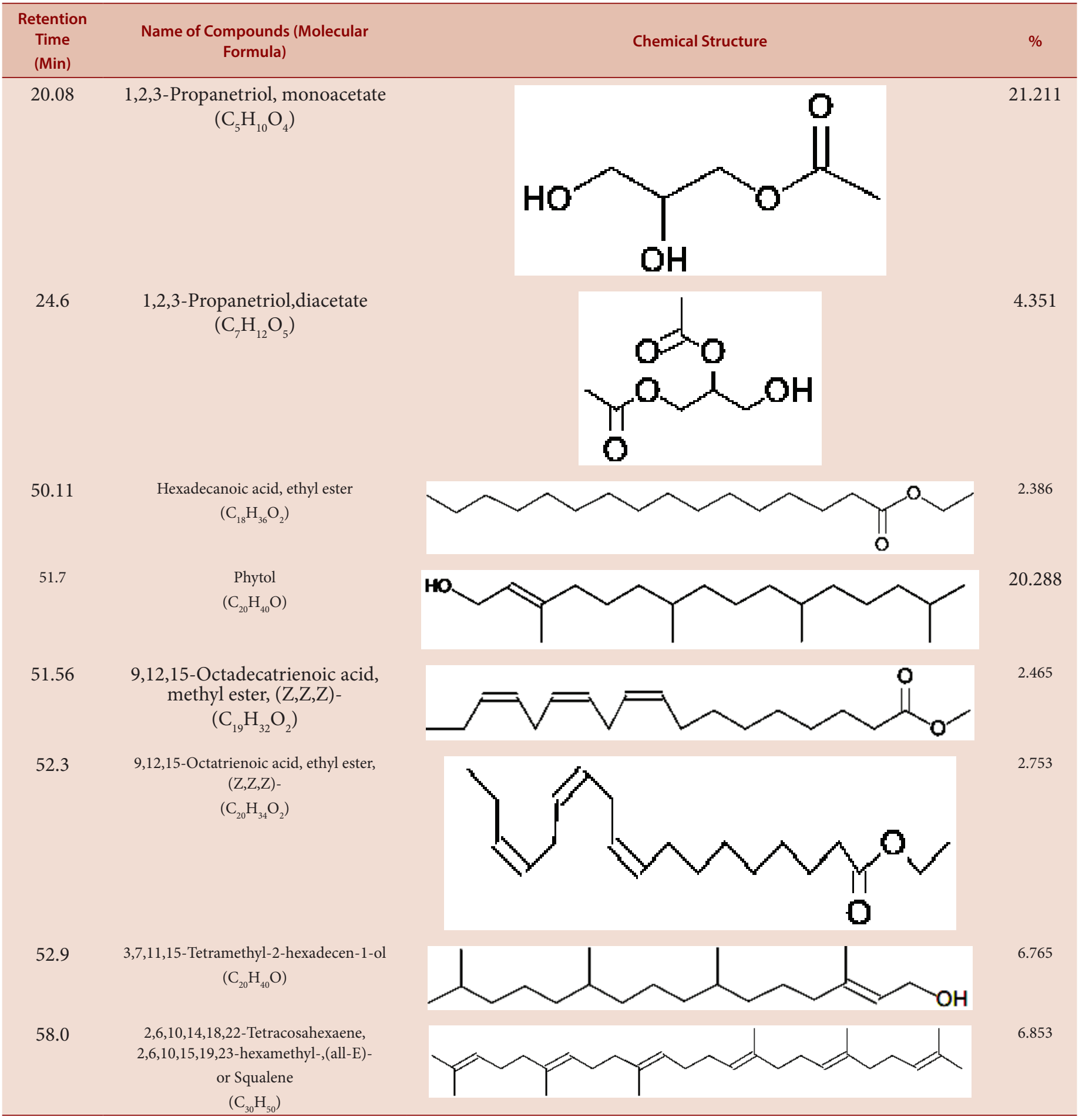

B. luzonica ethyl acetate leaf extract compared to the standard with $\mathrm{p}=0.001$ indicating that the extract is more potent than that of the standard since the concentration of ethyl acetate extract that inhibit $50 \%$ of the hepg2 cell lines is lower $(1.118 \mu \mathrm{g} / \mathrm{ml})$ significantly than that of the standard $(5.08 \mu \mathrm{g} / \mathrm{ml})$.this means that ethyl acetate extract has greater cytotoxic activity than doxorubicin. This study is the first one to report the cytotoxicity of the crude ethyl acetate extract obtained from B.luzonica leaves.

\section{CONCLUSION}

Based on the results, this endemic and edible plant from the philippines contains bioactive compounds demonstrated marked cytotoxicity against hepg2 can be a source of promising chemotherapeutic agent.

\section{ACKNOWLEDGEMENT}

This research was supported by the Graduate School, Faculty of Pharmacy, Office of Grants, Endowment and Partnerships in Higher Educa- 


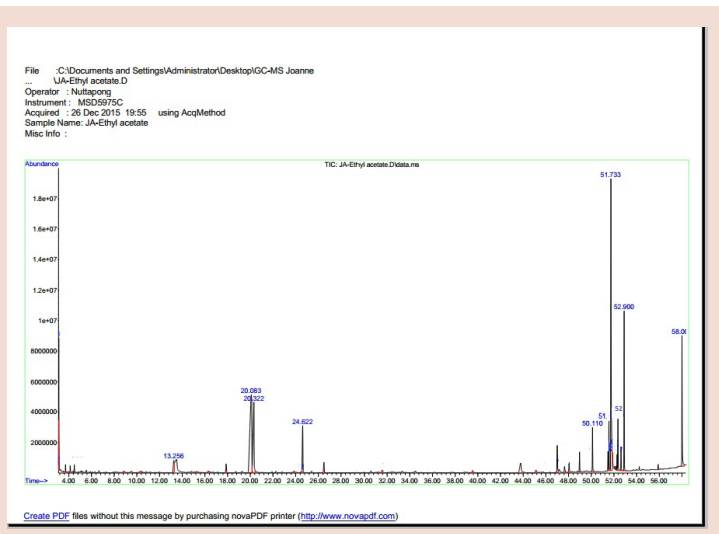

Figure 1: GC-MS Chromatogram of the Ethyl Acetate Extract from B. luzonica Leaves.

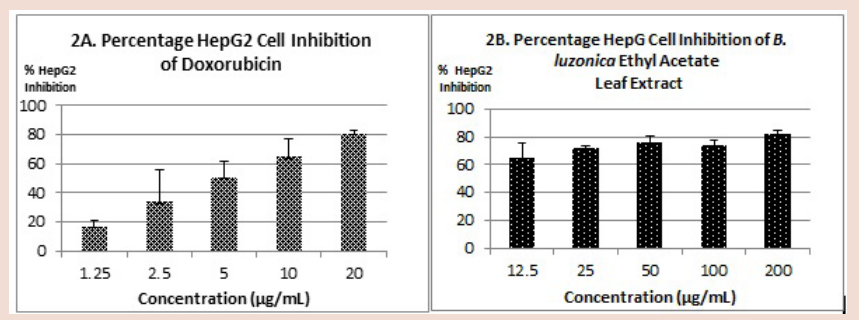

Figure 2: Percentage HepG2 Cell Inhibition of Doxorubicin (2A) and Ethyl Acetate Extract (2B).

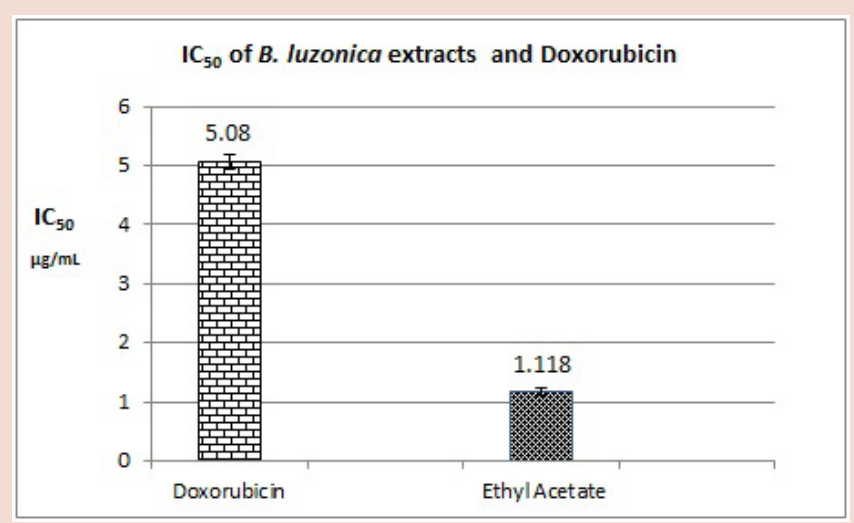

Figure 3: Comparison of the $\mathrm{IC}_{50}$ of Doxorubicin and Ethyl Acetate Extract.

tion, Mammalian Tissue Culture Laboratory (MTCL), Research Center for Natural and Applied Sciences (RCNAS), University of Santo Tomas (UST) Manila, Philippines Department of Science and Technology (DOST) and Commission on Higher Education (CHED), Philippines. Acknowledgement is extended to Asst. Prof. Ophelia Laurente, botanistcurator of UST Herbarium, RCNAS and Nuttapong of Nanocast Laboratory, Physical Sciences Mahidol University, Thailand.

HepG2 cell lines were kindly donated by Librado Santiago, Ph.D., to MTCL, RCNAS, UST, Manila, Philippines, which were purchased from European Collection of Authenticated Cell Cultures (ECACC).

\section{CONFLICT OF INTEREST}

We declare that we have no conflict of interest.

\section{ABBREVIATIONS USED}

HepG2: Hepatocellular Carcinoma Cell Lines; MTT: 3-(4,5-Dimethylthiazol-2yl)-2,5-Diphenyltetrazolium Bromide; TNF- $\alpha$ : Tumor Necrosis Factor Alpha; $\mathbf{I C}_{50}$ : Concentration in $\mu \mathrm{g} / \mathrm{mL}$ that will inhibit $50 \%$ of cell population; GC-MS: Gas Chromatography-Mass Spectrometry.

\section{REFERENCES}

1. Stewart B, Wild C, Editors. World Cancer Report 2014 . International Agency For Research On Cancer, World Health Organization Press:France. 2016.

2. Gomez Sl, Noone Am, et al... Cancer Incidence Trends Among Asian American Populations In The United States, 1990-2008. J Natl Cancer Inst. 2013;105(15):1096-110.

3. Siegel R, Ma J, Zou Z, Jemal A. Cancer Statistics. Ca Cancer J Clin. 2014;64(1):929

4. Bruix J, Sherman M, American Association For The Study Of Liver Diseases: Management Hepatocellular Carcinoma: An Update. Hepatology. 2011;53(3):1020-2

5. Singh Bn, Singh Br, Sarma Bk, Singh Hb.Potential Chemoprevention Of N-Nitrosodiethylamine-Inducedhepatocarcinogenesis By Polyphenolics From Acacia Nilotica Bark.Chembiol Interact. 2009:181(1):20-8.

6. Nasr M, Selima E, Hamed O, Kazem A. Targeting Different Angiogenic Pathways Withcombination Of Curcumin, Leflunomide And Perindopril Inhibits Diethylnitrosamine-Induced Hepatocellular Carcinoma In Mice. Eur J Pharmacol. 2014;723:267-275.

7. Lin L, Gao Q, Cuie C, Zhao H, Fu L, Liming C, Et Al. Isolation And Identification Of Ent-Kaurane-Type Diterpenoids From Rabdosiaserra (Maxim.) Hara Leaf And Their Inhibitory Activities Against Hepg-2, Mcf-7, And HI-50 Cell Lines.Food Chem. 2012:131(3):1009-14.

8. Nazir S, Hussain T, Ayub A, Rashid U, Macrobert Aj. Nanomaterials In Combating Cancer: Therapeutic Applications And Developments. A Review. Nanomedicine: Nanotechnol. 2014;10(1):19-34.

9. Warletaf, Campos M, Allouche Y, Sancez-Quesada C, Ruiz Mora J, Beltran G, Et Al. Squalene Protects Against Oxidative Dnadamage In Mcf10a Human Mammary Epithelial Cells But Not In Mcf7 And Mda-Mb-231 Human Breast Cancer Cells. Food Chemtoxicol, 2010;48(4):1092-100.

10. Urdanibia I, Michelangeli F, Ruiz Mc, Milano B, Taylor B.Anti Inflammatory And Antitumoural Effects Of Uncariaguianensis Bark J Ethnopharmacol. 2013;150:1154-62

11. Ran Xk, Wang X, Liu Pp, Chi YX, Wang Bj, Dou Dq, et al. Cytotoxic Constituents From The Leaves of Broussonetiapapyrifera. Chin J Nat Med. 2013;11(3):269-73.

12. Bachrach Zy, Contribution Of Selected Medicinal Plants For Cancer Prevention And Therapy.Sci J Fac Med. 2012;29:117-23.

13. Atanasov Ag, Waltenberger B, Pferschy-Wenzig Em, Linder T, Wawrosch C, Uhrin P, TemmlV, et. al. 2015. Discovery And Resupply Of Pharmacologically Active Plant-Derived Natural Products: A Review. Biotech Adv. 2015;33(8):1582-614.

14. Zulkipli In, David Sr, Rajabalaya R, Idris A. Medicinal Plants: A Potential Source Of Compounds For Targeting Cell Division. Drug Target Insights. 2015;9:9-19.

15. Tantengco Oa, Jacinto, Sd, Cytotoxic Activity Of Crude Extracts And Fractions From Premna Odorata (Blanco), Artocarpuscamansi (Blanco) And Gliricidasepium (Jacq) Against Selected Human Cancer Cell Lines. Asian Pac J Trop Biomed. 2013;5(12):1037-41.

16. Olarteei, Herrera Aa, Villasenor Im, Jacinto Sd. In Vitro Anti Tumor Properties Of An Isolate From Leaves Of Cassia Alata L. Asian Pac J Cancer Prev. 201314(5):3191-6.

17. Aboul-Enein Am, Abu El-Ela F, Shalaby Ea, El-Shenny Ha, Traditional Medicinal Plants Research In Egypt: Studies On Anti-Oxidant And Anticancer Activities. J Med Plants Res. 2012;6(5):689-703.

18. Alves A, Sousa R, Reis R. In Vitro Cytotoxicity Assessment Of Ulvan, A Polysaccharide Extracted From Green Algae.Phytother Res.2013;27(8):1143-8.

19. Sarac N.Antioxidant, Mutagenic, And Antimutagenic Activities Of Tragopogonlongirostis Var. Longirostis, An Edible Wild Plant In Turkey.Indian J Pharmacol. 2015;47(4):414-8.

20. bortolotto Lm, Amorozo Mc, Neto Gg, Oldeland J, Damasceno Ga Jr. Knowledge And Use Of Wild Edible Plants In Rural Communities Along Paraguay River, Pantanal, Brazil.Jethnobiol ethnomed. 2015;11(1):1-14.

21. JuY, Zhuo J, Liu B, Long C. Eating From The Wild: Diversity of Wild Edible Plants Used By Tibetans In Shangri-La Region Yunnan China. J Ethnobiol ethnomed. 2013;9(1):1.

22. Alberto A, Galvez C. Handbook on Trees. Quezon City, Philippines: Rex Bookstore Inc. 2014

23. Guo F, Feng L, Huang $C$, Ding $H$, Zhang $X$, Wang Z,et al. Phenylflavone Derivatives From Broussonetiapapyrifera Inhibit The Growth of Breast Cancer Cells In vitro and In vivo. Phytochem Lett. 2013;6(3):331-6.

24. Ryu Hw, Lee Jh, Kang Je, Jin Ym, Park Kh. Inhibition of Xanthine Oxidase By Phenolic Phytochemicals Frombroussonetiapapyrifera. J Korean Society Appl 
Bi. 2012;55(5):587-94.

25. Wu Wt. Evaluation of The Anti-Inflammatory Effects of Broussonetiapapyrifera Stem Bark. I J of Pharmacol.2012;44(1):26-30.

26. Sousa Eo, Costa Jgm. Genus Lantana: Chemical Aspects And Biological Activities A Review.Rev Bras Farmacogn. 2012;22(5):1115-80

27. Buss A., Butlerm. Editors. Natural Product Chemistry For Drug Discovery. Campbridge, United Kingdom: The Royal Society of Chemistry. 2010.

28. Majekodunmi So. Review of Extraction of Medicinal Plants for Pharmaceutical Research. A Review. Merit Res J Med Med Sci. 2015:3(11):521-7.

29. Mossmann T. Rapid Colorimetric Assay For Cellular Growth and Survival: Application to Proliferation and Cytotoxicity Assays. J Immunol Methods. 1983;65(1-2):55-63.

30. Patel S, Gheewala N, Suthar A, Shah A. In-vitro Cytotoxicity Activity of Solanum Nigrum Extract Against Hela Cell Line and Vero Cell Line. Int J Pharm Pharm Sci. 2009;1(1):38-46

31. Paulson Ds.Biostatistics And Microbiology: A Survival Manual, Bioscience Laboratories, Inc. Bozeman, Mt, Usa. 2008.

32. Ansilpn, Wills P J,Varum R, Latha, Ms. Cytotoxic and Apoptotic Activities of Amorphophallus campanulatus (Roxb.) Bl. Tuber Extracts Against Human Colon Carcinoma Cell Line Hct-15. Saudi J Biol Sci. 2014;21(6):524-31.

33. Kanno S, Kurauchi K, Tomizawaa, Yomogida S, Ishikawa M. Pifithrin-Alpha Has A P23-Independent Cytoprotective Effect on Docosahexaenoic Acid-Induced Cytotoxicity In Human Hepatocellular Carcinoma Hepg2 Cells. Toxicol Lett. $2015 \cdot 22 \cdot 232(2) \cdot 393-402$
34. Cho W. Editor. Materia Medica for Various Cancer.Springer Science + Business Media B.V. 2012.

35. Ogunlesi M, Okiei W, Ofor E, Osibete Ae. African Journal of Biotechnology 2009;8:7042-7050

36. Satyal P, Dosokyns, Poudol A, Setzer Wn. Essential Oil Constituent and Their Biologic Activities From The Leaves of Cassia Fistula Growing in Nepal. J Med Aromat Plants. 2012;3(2):1-4.

37. Foo LW, Salleh E, Mamat SNH. Extraction And Qualitative Analysis of Piper Betle Leaves For Antimicrobial Activities. Int J Eng Tech Sc Res. 2015;2:1-8.

38. Juneious C, Rani E. Molecular Biological Determination of Pkc Inhibitory Effects of 1,2,3-Propanetriol Monoacetate Produced Form Marine Sponge Associated Bacteria. $3^{\text {rd }}$ International Conference on Clinical Microbioloby and Microbial Genomics, 2014:3:5

39. Das B, Antoon R, Tsuchida P, Lofti S, Mirozova O, Farhat W, et al. Squalene Protects Mouse Bone Marrow Progenitors Against Cisplatin and CarboplatinInduced Cytotoxicity In vivo Without Protecting Tumor Growth. Neoplasia. 2008;10(10):1105-19.

40. Spanova M, Drum G. Squalene-Biochemistry, Molecular Biology, Press Biotechnology And Applications. Eur J Lip Sci Tech. 2011;113(11):1299-320.

41. Mahavorasirikul W, Viyanant $V$, Chaijaroenkul W, Itharat $A$, Na-Bangchang $K$. Cytotoxic Activity of Thai Medicinal Plants Against Human Cholangiocarcinoma, Laryngeal and Hepatocarcinoma Cells In vitro.Bmc Complement Altern Med. 2010:10(1):1.

\section{PICTORIAL ABSTRACT}

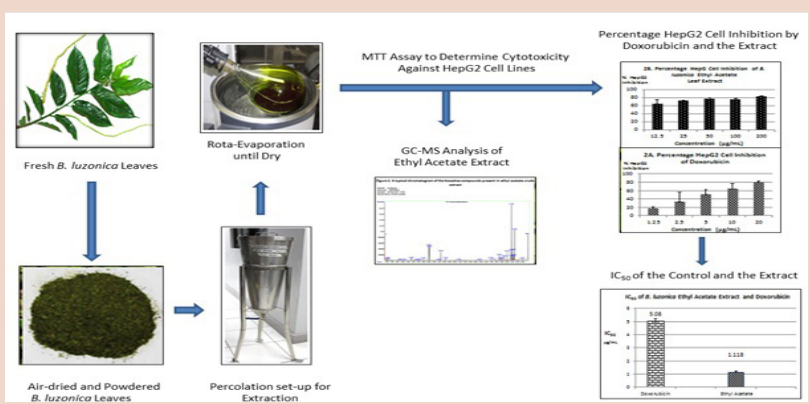

\section{SUMMARY}

- The main components of ethyl acetate extract of $B$. luzonica leaves are 1,2,3-propanetriol, monoacetate, phytol and squalene.

- At different concentrations, the ethyl acetate extract showed marked inhibiton of HepG2 cell lines.

- The ethyl acetate extract $\left(\mathrm{IC}_{50}=1.118 \mu \mathrm{g} / \mathrm{mL}\right)$ showed more potent cytotoxicity than doxorubicin $\left(\mathrm{IC}_{50}=5.068 \mu \mathrm{g} / \mathrm{mL}\right)$ against HepG2 cell lines.

\section{ABBREVIATIONS USED}

HepG2: Hepatocellular Carcinoma Cell Lines; MTT: 3-(4,5-Dimethylthiazol-2yl)-2,5-Diphenyltetrazolium Bromide; TNF- $\alpha$ : Tumor Necrosis Factor Alpha; $\mathbf{I C}_{50}$ : Concentration in $\mu \mathrm{g} / \mathrm{mL}$ that will inhibit $50 \%$ of cell population; GC-MS: Gas Chromatography-Mass Spectrometry.

\section{ABOUT AUTHORS}

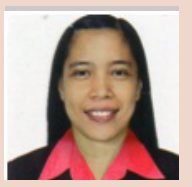

Franelyne P. Casuga: Is a doctoral student at the University of Santo Tomas taking Ph.D. in Pharmacy degree. She graduated with Bachelor of Science in Pharmacy and Master of Science in Pharmacy in Centro Escolar University. Her study focused on In vitroCytotoxicity and In vivo Anti-inflammatory and Hepatoprotective Properties of Plants.

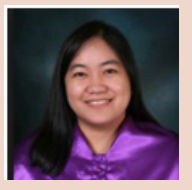

Mary Jho-Anne T. Corpuz: Obtained her Ph.D. in Pharmacy Degree from the Graduate School, University of Santo Tomas. She is currently affiliated with the Faculty of Pharmacy in the same university. Her study focused on the Antioxidant, Chemopreventive property and Cytotoxicity of plants. Furthermore included in her specialties are preformulation and formulation studies.

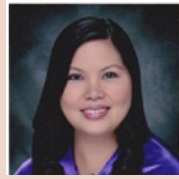

Agnes L. Castillo: Obtained her Ph.D. in Pharmacy degree from the Graduate School, University of Santo Tomas. She is currently affiliated with the Faculty of Pharmacy in the same university. Her study focused on clinical study of scabicidal and immunomodulatory effects of natural products, preformulation and formulation studies. 